\title{
ADDITIONS TO THE VASCULAR FLORA OF THE CYPRESS HILLS, ALBERTA
}

\author{
by B. de Vries, Fort Qu'Appelle, Saskatchewan, and C. D. Bird, \\ Department of Biology, University of Calgary, Alberta
}

\section{Introduction}

The Cypress Hills of southwestern Saskatchewan and southeastern Alberta have long been of interest to naturalists and the general public (Alberta Society of Petroleum Geologists, 1965; Bird \& Halliday, 1967). They are, however, still inadequately known from a scientific standpoint.

A detailed survey of the vascular plants of the region was made by Breitung (1954). Recent studies by both of us have shown, however, that a large number of additional species occur in the Cypress Hills of Alberta, that some of these are new to the Cypress Hills as a whole, and that a few are apparently new to the flora of Alberta.

An especially interesting aspect of the flora of the region is the presence of a Cordilleran element (Breitung, 1954; Bird, 1962). The present additions and evaluation of earlier reports have allowed us to present a more accurate portrayal of this group.

Specimens have been deposited in the Herbarium of the University of Calgary, and in that of the Canada Department of Agriculture, Ottawa. All collections reported herein were made within the boundaries of the Cypress Hills Provincial Park, Alberta.

\section{Acknowledgments}

The field work of the first author was supported by the University of Calgary, and that of the second author by the National Research Council of Canada. Grateful appreciation is extended to Dr. B. Boivin, who examined many of the critical specimens.

\section{New Records}

\section{Data and Discussion}

Breitung (1954) reports 664 taxa as occurring in the Cypress Hills as a whole. However, if one follows recent taxonomic changes and the more conservative treatment of Moss (1959), 21 of these can be regarded as synonyms. Breitung's paper gives the superficial impression that the vascular fiora of the Cypress Hills is well known. This may be true of the Saskatchewan side where 600 taxa were reported but it is definitely not true of the Alberta side where only 241 were reported.

Eighty-three of the taxa which Breitung recorded only for the Saskatchewan side of the Hills, have now been found by us on the Alberta side. They are: Equisetum scirpoides, Botrychium virginianum, Phalaris arundinacea, Carex bebbii, Juncus ensifolius, Allium textile, Zygadenus gramineus, Corallorhiza maculata, $C$. trifida, Salix bebbiana, S. planifolia, Commandra pallida, Rumex mexicanus, Claytonia lanceolata, Arenaria lateriflora, Cerastium arvense, Stellaria longifolia, S. longipes, Delphinium bicolor, Ranunculus cardiophyllus, Corydalis aurea, . Arabis divaricarpa, A. hirsuta, Cardamine scutata (C. pensylvanica), Erysium cheiranthoides, Lesquerella arenosa, Mitella nuda, Ribes hudsonianum, Amelanchier alnifolia, Crataegus chrysocarpa, Fragaria virginiana var. glauca (F. glauca), Geum macrophyllum var. perincisum, $G$. triflorum, Prunus pensylvanica, $P$. virginiana var. melanocarpa, Rubus pubescens, $R$. strigosus, Spiraea lucida, Astragalus agrestis, $A$. missouriensis, $A$. triphyllus, Hedysarum alpinum var. americanum, Lathyrus ochroleucus, Oxytropis sericea var. spicata, Vicia americana, Viola adunca, $V$. nephrophila, V. nuttallii, $V$. renifolia, Elaeagnus commutata, Shepher- 
dice canadensis, Oenothera biennis, Heracleum lanatum, Perideridia gairdneri, Sanicula marilandica, Cornus canadensis, $C$. stolonifera, Moneses uniflora, Pyrola asarifolia, P. elliptica, Arctostaphyllos uva-ursi, Lysimachia ciliata, Primula incana, Collomia linearis, Phlox hoodii, Cryptantha bradburiana, Moldavica parviflora, Collinsia parviflora, Penstemon nitidus, Veronica americana, Galium boreale, Linnaea borealis, var. americana, Symphoricarpos albus, S. occidentalis, Viburnum edule, Campanula rotundifolia, Antennaria aprica, $A$. campestris var. athabascensis, Arnica cordifolia, Erigeron philadelphicus, Gaillardia aristata, Lactuca pulchella and Petasites sagittatus.

Twenty-six taxa found by us in Alberta were not recorded from either the Saskatchewan or the Alberta side of the Cypress Hills by Breitung. They are: Lycopodium complanatum, Najas flexilis, Carex platylepis, C. praegracilis, Juncus tracyi, Salix padophyla, Silene noctiflora, Anemone multifida var. hudsoniana, Ranunculus gmelinii, $R$. pedatifidus var. leiocarpus Arabis retrofracta var. collinsii, Barbarea vulgaris, Ribes oxyacanthoides var. saxosum, Agrimonia striata, Epilobium alpinus, Osmorhiza depauperata, O. purpurea, Androsace septentrionalis var. diffusa, $A$. septentrionalis var.subumbellata, A pocynum androsaemifolium var. pumilum, Dracocephalum nuttallii, Veronica serpyllifolia var. humifusa, Aster laevis var. geyeri, Chrysanthemum leucanthemum, Hieracium cynoglossoides, Senecio pauperculus, var. firmifolius.

Ranunculus pedatifidus var. leiocarpus, Arabis retrofracta var. collinsii, Ribes oxyacanthoides, var. saxosum, Apocynum androsaemifolium var. pumilum, and Senecio pauperculus var. firmifolius are apparently new to Alberta, as they are not recorded by Moss (1959).

\section{The Cordilleran Element}

Breitung (1954) compiled a list of 85 taxa which he felt belonged to the Cordilleran element. Our studies have revealed, however, that this number can be reduced to 55 if one follows the more conservative nomenclature of Moss (1959) and if one takes into account new information on the geographical distribution of some of the species. In addition, three of the new taxa reported by us bring the revised total to 58. Those taxa which we regard as being Cordilleran are: Pinus contorta var. latifolia, Alopecurus occidentalis (A. glaucus), Bromus marginatus, Danthonia californica, Festuca idahoensis, Poa ampla (P. nevadensis), Stipa columbiana, Trisetum wolfii, Carex hoodii, $C$. microptera, C. pachystachya, C. petasata, C.raynoldsii, C. simulata, Juncus ensifolius, J. saximontanus, Goodyera oblongifolia, Salix caudata, S. drummondiana, S. pseudocordata, Betula papyrifera var. subcordata, Polygonum bistortoides, Claytonia lanceolata, Montia linearis (Claytonia linearis), Arenaria capillaris var. americana (A. congesta), Clematis verticellaris var. columbiana, Ranunculus cardiophyllus, R. inamoenus, R. pedatifidus var. affine, Thalictrum occidentale, Heuchera flabellifolia, Saxifraga rhomboidea, Crataegus columbiana, $C$. douglasii, Potentilla diversifolia, Rubus parviflorus, Sorbus scopulina, Spiraea lucida, Astragalus vexilliflexus, Lomatium dissectum var. multifidum (Leptotaeria multifida), Osmorhiza purpurea, Perideridea gairdneri, Chimaphila umbellata var. occidentalis, Monotropa hypopithys ( $M$. lanuginosa), Pterospora andromedea, Lithospermum ruderale, Besseya cinerea, Mimulus guttatus, Antennaria corymbosa, Arnica cordifolia, Aster eatonii ( $A$. oregonus), Crepis atrabarba (C. exilis), $C$. intermedia, $C$. occidentalis, Erigeron radicatus, Hieracium albiflorum, $H$. cynoglossoides and Senecio integerrimus var. exaltatus (S. exaltatus). This element comprises $8.6 \%$ of the overall total for the Hills.

Six of the plants regarded by Breitung as Cordilleran, and two of ours, have arctic-alpine or sub arcticalpine distribution patterns. Those comprising the first are Calamagrostis purpurascens, Hordeum, brachyanthe- 
rum, Arenaria rubella, Ranunculus pedatifidus var. leiocarpus and Erigeron compositus; while those making up the second group are Barbarea orthoceros, Epilobium alpinus and Erigeron acris var. asteroides ( $E$. droebachiensis).

\section{Summary}

One hundred and nine taxa are added to the vascular flora of the Cypress Hills of Alberta, thereby raising the total to 350 . Eighteen taxa, including nine varieties, are added to the Cypress Hills as a whole, thus making a total of 669 . One species and four varieties are reported as new to Alberta.
A reinterpretation of the vascular flora of the Cypress Hills reveals that 58 , or $8.6 \%$ of the taxa, belong to the Cordilleran element.

\section{LITERATURE CITED}

Alberta Society of Petroleum Geologists. 1965. Guidebook, Cypress Hills Plateau, Alberta and Saskatchewan: 15th Annual Field Conference.

Bird, C. D. 1962. Bryophytes of the Cypress Hills Provincial Parks, Alberta and Saskatchewan. Canadian Journal of Botany 40: 573-587.

Bird, C. D. \& I. A. R. Halladay. 1967. The Cypress Hills. pp. 117-133, in Alberta - a natural history. M. G. Hurtig Publishers, Edmonton, Alberta.

Breitung, A. J. 1954. A botanical survey of the Cypress Hills. Canadian Field-Naturalist $68: 55-92$.

Moss, E. H. 1959. Flora of Alberta. University of Toronto Press.

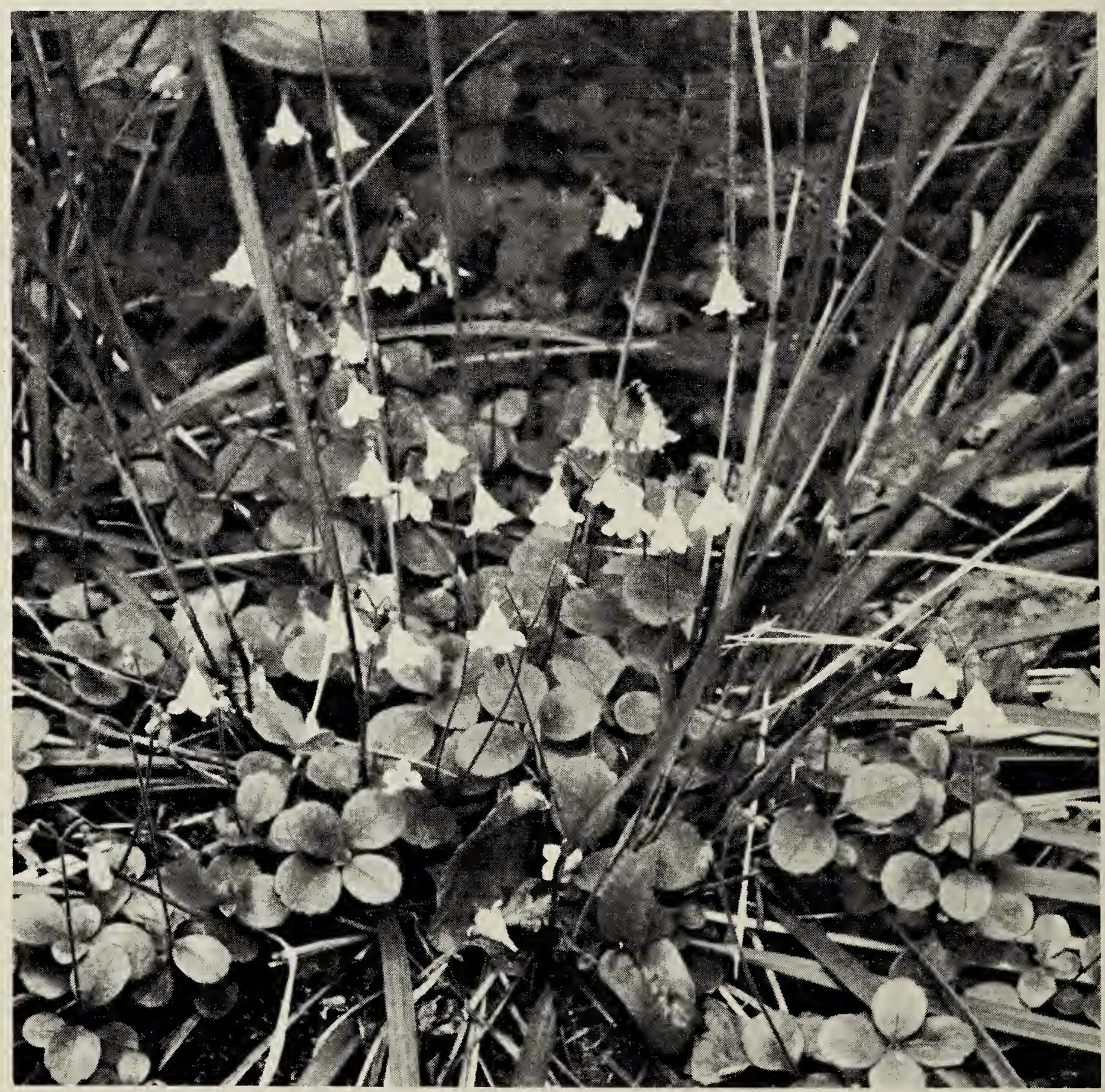

Twinflower

Photo by Harold Hosford, 4116 Roblin Blvd., Winnipeg 